\title{
TINGKAT PEMAHAMAN DAN SURVEI LEVEL AKTIVITAS FISIK, STATUS KECUKUPAN ENERGI DAN STATUS ANTROPOMETRIK MAHASISWA PROGRAM STUDI PENDIDIKAN KEPELATIHAN OLAHRAGA FIK UNY
}

\author{
Oleh: Prijo Sudibjo, Novita Intan Arovah, Rachmah Lakmi A \\ Dosen Jurusan Pendidikan Kesehatan dan Rekreasi FIK UNY
}

\begin{abstract}
Abstrak
Mahasiswa Program Studi Pendidikan Kepelatihan Olahraga Fakultas Ilmu Keolahragaan dipersiapkan menjadi pelatih yang kompeten. Salah satu kompetensi yang diperlukan oleh pelatih adalah pemahaman dan keterampilan dalam pengukuran tingkat aktivitas fisik, status kecukupan energi dan status antropometrik. Tujuan penelitian ini adalah untuk mengetahui dan memahami pengukuran level aktivitas fisik, status kecukupan energy, dan status antropometrik mahasiswa Program Studi Pendidikan Kepelatihan Olahraga FIK UNY.

Penelitian ini merupakan penelitian observasi cross sectional pada 30 mahasiswa Program Stusi Pendidikan Kepelatihan Olahraga FIK UNY yang telah menempuh mata kuliah Anatomi. Pengukuran tingkat pemahaman dilaksanakan dengan metode tes. Level aktivitas fisik diukur dengan kuesioner IPAQ (International Physical Activity Questionnaire), status kecukupan energi diukur dengan membagi antara asupan kalori dibagi dengan kebutuhan kalori, dan status antropometris dinilai dengan menggunakan rumus BMI (body mass index) dan somatotype berdasarkan Health Charter Manual. Data diolah secara deskriptif dan korelatif menggunakan analisis Korelasi Pearson untuk melihat hubungan antara tingkat pemahaman dan status level aktivitas fisik, status kecukupan energy, dan status antropometrik dengan program SPSS.

Hasil penelitian menunjukkan bahwa pada semua mahasiswa Program Studi Pendidikan Kepelatihan Olahraga FIK UNY mempunyai level aktivitas fisik yang baik (skor IPAQ rata-rata 7248,13 $\pm 2420,58$ METS), dan status kecukupan energi yang baik pula (rata-rata kecukupan energi sebesar 96,62 $\pm 19,81 \%$ ). Di sisi lain, status gizi pada $90 \%$ mahasiswa menunjukkan kriteria yang normal. Uji Korelasi Pearson menunjukkan adanya korelasi positif yang sangat kuat antara tingkat pemahaman level aktivitas fisik dan level aktivitas fisik (korelasi 0.902 dan $\mathrm{p}<0,05$ ), namun tidak terbukti adanya korelasi yang signifikan $(\mathrm{p}>0,05)$ antara tingkat pemahaman dan status kecukupan energi dan status gizi yang secara berurutan didapatkan nilai korelasi sebesar 0,27 dan 0,048.
\end{abstract}

Kata Kunci: level aktivitas fisik, status kecukupan energi, status antropometrik

Tingkat Pemahaman dan Survei Level Aktivitas Fisik, Status Kecukupan Energi dan Status Antopometri Mahasiswa Program Studi Pendidikan Kepelatihan Olahraga FIK UNY (Prijo Sudibjo, Novita Intan Arovah, Rachmah Lakmi A) 
Kesuksesan atlet dalam berprestasi tidak hanya ditunjang oleh ketrampilan dan teknik yang memadai namun juga harus ditunjang oleh profil anatomis (status antropometris) yang baik (Oja et al, 2004: 18). Untuk mendapatkan profil anatomis tersebut diperlukan strategi latihan fisik yang tepat serta status kecukupan energi yang baik. Sebagai calon pelatih olahraga, mahasiswa Program Studi Kepelatihan perlu memiliki tingkat pemahaman tentang pengukuran level aktivitas fisik, status kecukupan energi, dan status antropometrik. Dengan memiliki tingkat pemahaman yang baik seorang pelatih dapat mengelola atletnya sehingga dapat memiliki status antropometris yang optimal.

Antropometri merupakan bagian dari ilmu Anatomi yang mempelajari tentang teknik pengukuran tubuh manusia serta penentuan tipe tubuh seseorang (Jahari 1998: 54). Dalam ilmu keolahragaan, teknik antropometri berkembang untuk mengetahui status antropometri yang paling optimal dalam cabang olahraga tertentu. Di Fakultas Ilmu Keolahragaan, antropometri tercakup dalam mata kuliah Anatomi Manusia. Walaupun demikian pada sejak diberlakukannya pemutakhiran kurikulum pada tahun 2009, mata kuliah Anatomi mengalami perubahan struktur karena terjadi pengurangan jumlah satuan kredit semester (SKS) dari 4 SKS menjadi 3 SKS. Perubahan jumlah SKS tersebut menimbulkan perubahan sistem pembelajaran antropometri. Antropometri tidak lagi dimasukkan pada materi praktikum dan diubah menjadi mata kuliah teori yang tidak dipraktikkan.

Perubahan sistem pembelajaran anatomi khususnya antropometri perlu dievaluasi khususnya pada mahasiswa Program Studi Pendidikan Kepelatihan Olahraga mengingat pemahaman tentang tingkat pengukuran aktivitas fisik, status kecukupan energy, dan status antropometrik diperlukan untuk melakukan evaluasi pada atlet dalam rangka mendukung optimalisasi pencapaian prestasi atlet. Tingkat pemahaman tersebut perlu dikorelasikan dengan pelaksanaan usaha peningkatan keseimbangan antara tingkat aktivitas fisik dan pemenuhan kebutuhan energi. (Reeves Jr et al, 1999: 79) Data dari penelitian ini selanjutnya penting digunakan sebagai dasar perencanaan pembelajaran antropometri olahraga dalam lingkup mata kuliah Anatomi untuk mengoptimalkan kompetensi mahasiswa Program Studi Pendidikan Kepelatihan Olahraga FIK UNY di bidang Antropometri Olahraga. 


\section{KAJIAN PUSTAKA}

\section{Pengertian Aktivitas Fisik dan Kepentingan Pengukurannya pada Atlet}

Aktivitas fisik adalah segala kegiatan atau aktivitas yang menyebabkan peningkatan energi oleh tubuh melampaui energi istirahat. Aktivitas fisik disebut juga aktivitas eksternal, yaitu sesuatu yang menggunakan tenaga atau energi untuk melakukan berbagai kegiatan fisik, seperti berjalan, berlari, dan berolahraga (Haskell et al, 2007: 1423). Setiap kegiatan fisik membutuhkan energi yang berbeda menurut lamanya intensitas dan sifat kerja otot. Latihan fisik dapat meningkatkan kemampuan fungsional dan menurunkan kebutuhan oksigen otot jantung yang diperlukan pada setiap penurunan aktivitas fisik seseorang. Aktivitas fisik adalah gerakan yang dilakukan oleh otot tubuh dan sistem penunjangnya (Wilmore et al, 2004). Selama aktivitas fisik, otot memerlukan energi di luar metabolisme untuk bergerak. Banyaknya energi yang diperlukan bergantung pada seberapa berat pekerjaan yang dilakukan.

Atlet pada umumnya memiliki level aktivitas fisik yang tinggi. Pengukuran level aktivitas fisik pada atlet penting dilakukan sebagai bentuk evaluasi program latihan yang telah dilaksanakan (Wilmore et al, 2004). Hasil evaluasi tersebut diperlukan untuk perencanaan program latihan lanjutan. Selain itu, hasil pengukuran tingkat aktivitas fisik diperlukan untuk mengukur kebutuhan energi atlet. Asupan makanan dapat disesuaikan dengan kebutuhan kalori atlet. Dengan demikian status kecukupan energi atlet dapat dioptimalkan. Level aktivitas fisik dan status kecukupan energi yang optimal kemudian dapat mendukung status antropometri yang ideal pada atlet (Reeves Jr et al, 1999: 79).

\section{Pengukuran Aktivitas Fisik}

Berbagai teknik dapat dilakukan untuk mengukur tingkat aktivitas fisik seseorang. Instrumen standar yang digunakan adalah teknik double-labeled water. Walaupun demikian teknik ini sulit dilakukan sehingga disusun berbagai jebis teknik alternatif meliputi kuesioner, accelerometry atau pedometry (Oja et al, 2004: 18).

Pada penelitian ini, metode untuk mengukur aktivitas fisik menggunakan kuesioner, yaitu International Physical Activity Questionaire (IPAQ) (Booth et al, 2003: 1381).

Tingkat Pemahaman dan Survei Level Aktivitas Fisik, Status Kecukupan Energi dan Status Antopometri Mahasiswa Program Studi Pendidikan Kepelatihan Olahraga FIK UNY (Prijo Sudibjo, Novita Intan Arovah, Rachmah Lakmi A) 
Kelebihan instrumen ini adalah cepat, bisa dilakukan secara masal, dan telah di validasi di berbagai negara termasuk di Indonesia. Walaupun demikian, terdapat kekurangan dalam penggunaan kuesioner, yaitu bergantung pada kemampuan subjek untuk mengingat kembali kebiasaannya secara rinci. Selain itu, kuesioner juga sulit untuk mengonversikan informasi aktivitas yang kualitatif (misalnya bermain selama 30 menit) menjadi data yang kuantitatif (misalnya kkal/waktu latihan). Oleh sebab itu, konversi ini bergantung pada faktor aktivitas atau faktor intensitas yang disebut metabolic equivalents (METs) untuk tiap aktivitas, bahwa METs adalah kelipatan dari resting energy expenditure (REE) (Booth et a,. 2003: 1381).

Selanjutnya, hasil analisis tingkat aktivitas fisik menurut Guidelines for Data Processing and Analysis of the IPAQ dapat diklasifikasikan sebagai berikut:

1. Tingkat aktivitas fisik tinggi, bila memenuhi salah satu kriteria:

a. aktivitas intensitas berat 3 hari atau lebih yang mencapai minimal 1500 METsmenit/minggu, atau

b. kombinasi berjalan, aktivitas intensitas berat, dan sedang yang mencapai minimal 3000 METs-menit/minggu.

2. Tingkat aktivitas fisik sedang, bila memenuhi salah satu kriteria,

a. aktivitas intensitas berat 3 hari atau lebih selama 20 menit/hari,

b.aktivitas intensitas sedang atau berjalan minimal 30 menit/hari selama 5 hari atau lebih, atau

c.aktivitas intensitas berat, kombinasi berjalan yang mencapai 600 METsmenit/minggu selama 5 hari atau lebih.

3. Tingkat aktivitas fisik rendah, apabila tidak memenuhi semua kriteria di atas (Booth et al, 2003: 1381).

\section{Status Kecukupan Energi dan Perhitungannya}

Zat gizi atau zat makanan, merupakan bahan dasar penyusun bahan makanan. fungsi zat gizi antara lain, sebagai berikut:

1. Sumber energi atau tenaga.

2. Membantu pertumbuhan badan yaitu penambahan sel baru pada tubuh. 
3. Memelihara jaringan tubuh dan mengganti yang rusak atau habis terpakai

4. Mengatur metabolisme dan berbagai keseimbangan dalam cairan tubuh (keseimbangan air, asam, basa, dan mineral).

5. Berperan dalam mekanisme pertahanan tubuh terhadap berbaagai penyakit sebagai antioksidan dan antibodi lainnya (Jelliffe, 2006: 135).

Asupan kalori dan zat gizi menentukan ketersediaan sumber energi di tubuh. Kurangnya asupan kalori dan zat gizi akan berdampak pada berkurangnya kemampuan tubuh dalam melakukan aktivitas. Kontraksi otot memerlukan ATP, sementara persediaan ATP dalam otot terbatas sehingga tambahan energi diperlukan untuk mengganti atau membentuk ATP kembali. Pembentukan ATP memerlukan bahan baku dalam bentuk karbohidrat, lemak, atau protein. Karbohidrat, lemak, dan protein didapat dari asupan makanan yang dimakan setiap hari. Pemenuhan kebutuhan kalori dan zat gizi selalu harus terjaga dalam posisi seimbang. Kurangnya kualitas makanan yang diperoleh dalam diet sehari-hari dapat menurunkan tingkat kebugaran seseorang (Martins et al, 2003: 760).

Atlet cenderung memerlukan energi yang lebih banyak daripada non-atlet. Oleh karenanya asupan makanan yang diperlukan juga cenderung lebih banyak daripada atlet. Selain secara umum jumlah kalori yang diperlukan lebih banyak, kebutuhan protein atlet per kilogram berat badan juga lebih banyak daripada non-atlet. Kebutuhan normal nonatlet adalah sekitar 1 gram/kg BB sedangkan kebutuhan protein atlet adalah 1,5-2 gram/kg BB (Jahari, 1998: 54).

\section{Pengukuran Asupan Makanan (Survei Gizi)}

Survei diet atau penilaian konsumsi makanan adalah salah satu metode yang digunakan dalam penentuan status gizi peorangan atau kelompok. Metode pengukuran konsumsi makanan untuk individu antara lain:

\section{Metode Food Recall 24 Jam}

Prinsip metode ini adalah dilakukan dengan mencatat jenis dan jumlah bahan makanan yang dikonsumsi pada periode 24 jam yang lalu yang diperoleh dari hasil wawancara yang dilakukan oleh petugas yang sudah terlatih dengan menggunakan kuesioner terstruktur. Data yang diperoleh dari food recall cenderung lebih bersifat 
kualitatif, sehingga untuk mendapatkan data kuantitatif, jumlah konsumsi makanan individu ditanyakan secara teliti dengan menggunakan alat atau ukuran rumah tangga (URT) contoh sendok, gelas, piring, atau ukuran lainnya yang biasa dipergunakan sehari-hari. Apabila pengukuran dilakukan hanya dilakukan 1 kali (1×24 jam), data yang diperoleh kurang representatif untuk menggambarkan kebiasan makanan individu. Oleh karena itu, food recall 24 jam sebaiknya dilakukan berulang-ulang dan harinya tidak berturut-turut.

a. Kelebihan metode food recall 24 jam antara lain:

1) Mudah melaksanakannya tidak terlalu membebani responden.

2) Biaya relatif murah.

3) Cepat, sehingga dapat mencakup banyak responden.

4) Dapat digunakan untuk responden yang buta huruf.

5) Dapat memberikan gambaran nyata yang benar-benar dikonsumsi individu sehingga dapat dihitung intake zat gizi sehari.

b. Kekurangan metode food recall 24 jam antara lain:

1) Tidak dapat menggambarkan asupan makanan sehari-hari, apabila hanya dilakukan recall satu hari.

2) Ketepatannya sangat bergantung pada daya ingat responden (Lee-Han et al, 2009: 269).

2. Metode Estimated Food Record

Pada metode ini, responden diminta untuk mencatat semua yang dia makan dan minum setiap kali sebelum makan dalam ukuran rumah tangga (URT) atau menimbang dalam ukurang berat (gram) dalam periode tertentu (2-4 hari berturut-turut), termasuk cara persiapan dan pengolahan makanan tersebut (Supariasa, 2002 :18).

a. Kelebihan metode estimated food record antara lain:

1) Relatif murah dan cepat.

2) Dapat menjangkau sampel dalam jumlah besar.

3) Dapat diketahui konsumsi zat gizi sehari.

4) Hasilnya relatif lebih akurat.

b. Kekurangan metode estimated food record antara lain: 
1) Terlalu membebanin responden.

2) Tidak cocok untuk responden yang buta huruf (Lee-Han et al, 2009: 269).

3. Metode Penimbangan Makanan (Food Weighing)

Pada metode ini, responden atau petugas menimbang dan mencacat seluruh makanan yang dikonsumsi responden selama satu hari. Penimbangan ini biasanya berlangsung beberapa hari tergantung pada tujuan, dana penelitian, dan tenaga yang tersedia (Supariasa, 2002:18).

a. Kelebihan metode food weighing antara lain, data yang diperoleh lebih akurat/ teliti.

b. Kekurangan metode food weighing antara lain :

1) Memerlukan waktu dan cukup mahal.

2) Tenaga pengumpul data harus terlatih dan terampil.

3) Memerlukan kerja sama yang baik dengan responden (Lee-Han et al, 2009: 269).

4. Metode Riwayat Makan (Dietary History Method)

Metode ini bersifat kualitatif karena memberikan gambaran pola konsumsi berdasarkan pengamatan dalam waktu yang cukup lama (bisa 1 minggu, 1 bulan, atau 1 tahun). Hal yang harus diperhatikan dalam penggunaan metode ini adalah keadaan waktu-waktu tertentu seperti hari pasar, awal bulan, dan hari raya. Gambaran konsumsi pada hari-hari tersebut harus dikumpulkan.

a. Kelebihan dietary history method antara lain:

1) Dapat memberikan gambaran konsumsi pada periode yang panjang secara kualitatif dan kuantitatif.

2) Biaya relatif murah.

b. Kekurangan dietary history method antara lain:

1) Terlalu membebani pihak pengumpul data dan responden.

2) Sangat sensitif dan membutuhkan pengumpul data yang terlatih.

3) Tidak cocok dipakai untuk survei-survei besar (Lee-Han et al, 2009: 269).

5. Metode frekuensi makanan (Food Frequency Method)

Metode frekuensi makanan merupakan metode pengukuran konsumsi makanan untuk memperoleh data tentnag frekuensi konsumsi sejumlah bahan makanan atau

Tingkat Pemahaman dan Survei Level Aktivitas Fisik, Status Kecukupan Energi dan Status Antopometri Mahasiswa Program Studi Pendidikan Kepelatihan Olahraga FIK UNY (Prijo Sudibjo, Novita Intan Arovah, Rachmah Lakmi A) 
makanan jadi selama periode tertentu, seperti hari, minggu, bulan, atau tahun. Bahan makanan yang ada dalam daftar kuesioner tersebut adalah yang dikonsumsi dalam frekuensi cukup sering oleh responden (Supariasa, 2002).

a. Kelebihan metode frekuensi makanan antara lain:

1) Relatif murah dan sederhana.

2) Dapat dilakukan sendiri oleh responden.

3) Tidak membutuhkan latihan khusus.

b. Kekurangan metode frekuensi makanan antara lain:

1) Tidak dapat menghitung intake zat gizi sehari.

2) Sulit mengembangkan kuesioner pengumpulan data.

3) Responden harus jujur dan mempunyai motivasi tinggi.

Berikut ini merupakan tabel klasifikasi tingkat konsumsi.

Tabel 1. Klasifikasi Tingkat Konsumsi

\begin{tabular}{|c|c|}
\hline Kategori & Nilai \\
\hline Baik & $\geq 100 \%$ AKG \\
\hline Sedang & $>80-99 \%$ AKG \\
\hline Kurang & $70-80 \%$ AKG \\
\hline Defisit & $<70 \%$ AKG \\
\hline
\end{tabular}

(Livingstone et al. 2000: 293)

\section{Definisi Status Antropometri dan Status Gizi}

Status antropometri merupakan salah satu cara pengukuran status gizi seseorang. Status gizi merupakan cerminan ukuran terpenuhinya kebutuhan gizi. Status gizi secara parsial dapat diukur dengan antropometri, biokimia, atau klinis. Status gizi adalah keadaan tubuh sebagai akibat konsumsi makanan dan penggunaaan zat gizi. Status gizi dapat dibedakan atas status gizi buruk, kurang, baik, dan status gizi lebih. Menurut Irianto, status gizi merupakan ekspresi dari keadaan keseimbangan dalam bentuk variabel tertentu, dapat pula dikatakan bahwa status gizi adalah indikator baik buruknya penyediaan makanan sehari-hari dan status gizi yang baik, sangat diperlukan untuk dapat mempertahankan derajat kesehatan (Jahari, 1998: 54). 


\section{Status Antropometri sebagai Salah Satu Metode Penilaian Status Gizi}

Penilaian status gizi pada dasarnya merupakan proses pemeriksaan keadaan gizi seseorang dengan cara pengumpulan data penting, baik yang bersifat objektif maupun subjektif, untuk dibandingkan dengan standar yang telah dibakukan. Penilaian status gizi merupakan suatu program gizi untuk memantau status gizi masyarakat. Data yang diukur meliputi berat badan dan tinggi badan yang kemudian dikonversikan menjadi status gizi (Reeves Jr et $a$, 1999: 79).

Salah satu penilaian status gizi adalah dengan pengukuran antropometri. Pengukuran antropometri adalah pengukuran terhadap dimensi tubuh dan komposisi tubuh. Irianto mengungkapkan, bahwa pemeriksaan antropometri dilakukan dengan cara mengukur berat badan, tinggi badan, lingkar lengan atas, dan tebal lemak tubuh. Pengukuran antropometri bertujuan mengetahui status gizi berdasarkan satu ukuran menurut ukuran lainnya, dan pengukuran ini merupakan cara yang paling sering digunakan (Jahari, 1998: 54).

Salah satu cara penilaian antropometri adalah indeks massa tubuh (IMT). IMT merupakan pengukuran yang membandingkan berat dan tingg badan seseorang, dengan tujuan memperkirakan berat badan ideal dengan tinggi badan tertentu, cara mengukurnya dengan membagi berat badan dengan tinggi badan (dalam meter) yang dikuadratkan (Reeves Jr et al, 1999: 79).

Tabel 2. Klasifikasi IMT

\begin{tabular}{|c|l|c|}
\hline \multirow{2}{*}{ Kurus } & \multicolumn{1}{|c|}{ Kategori } & IMT \\
& Kekurangan BB tingkat ringan & $<17.0$ \\
\cline { 2 - 3 } & Kekurangan BB tingkat berat & $17.0-18.5$ \\
\hline Normal & & $18.5-25.0$ \\
\hline Gemuk & Kelebihan BB tingkat ringan & $25.0-27.0$ \\
\cline { 2 - 3 } & Kelebihan BB tingkat berat & $>27.0$ \\
\hline
\end{tabular}

\section{METODE PENELITIAN}

Tingkat Pemahaman dan Survei Level Aktivitas Fisik, Status Kecukupan Energi dan Status Antopometri Mahasiswa Program Studi Pendidikan Kepelatihan Olahraga FIK UNY (Prijo Sudibjo, Novita Intan Arovah, Rachmah Lakmi A) 
Penelitian ini merupakan penelitian observasi cross sectional pada 30 mahasiswa Program Studi Pendidikan Kepelatihan Olahraga FIK UNY yang telah menempuh mata kuliah Anatomi. Pada subjek tersebut diukur: (1) tingkat pemahaman tentang pengukuran level aktivitas fisik, status kecukupan energy, dan status antropometrik, dan (2) level aktivitas fisik, status kecukupan energy, dan status antropometrik. Pengukuran tingkat pemahaman dilaksanakan dengan metode tes. Hasil tes dievaluasi berdasarkan kisi-kisi jawaban untuk mengahasilkan skor yang berupa persentase pemahaman dengan skala $0 \%$ sampai $100 \%$. Level aktivitas fisik diukur dengan kuesioner pengukuran aktivitas fisik dari IPAQ (International Physical Activity Questionnaire).

Status kecukupan energi diukur dengan membagi asupan kalori dengan kebutuhan kalori. Asupan kalori dihitung dengan metode food recall. Hasil data food recall dan kebutuhan energi dihitung dengan rumus kebutuhan energi pada software nutrisurvey. Status antropometri dinilai dengan menggunakan rumus BMI (body mass index) dan somatotype berdasarkan Health Charter Manual. Data tingkat pemahaman dan level aktivitas fisik, status kecukupan energy, dan status antropometrik diolah secara deskriptif, serta dikorelasikan menggunakan analisis Korelatsi Pearson untuk melihat hubungan antara tingkat pemahaman dan status level aktivitas fisik, status kecukupan energy, dan status antropometrik dengan program SPSS.

\section{HASIL PENELITIAN}

Penelitian dilakukan di salah satu kelas Program Studi Pendidikan Kepelatihan Olahraga (PKO) yang mengambil mata kuliah Anatomi. Dari kelas tersebut didapatkan mahasiswa sejumlah 59 orang mahasiswa terdiri atas 58 laki-laki dan hanya didapatkan 1 mahasiswa perempuan. Kelas diberikan materi tentang level aktivitas fisik, status kecukupan energi, dan status antropometrik serta cara pengukurannya. Pada setiap sesi pertemuan diakhiri dengan pemberian tes untuk mengetahui tingkat pemahaman terhadap materi yang telah diberikan. Data dikumpulkan dari semua mahasiswa pada kelas tersebut. Hasil pengumpulan data didapatkan 30 orang mahasiswa yang mempunyai data lengkap tentang pemahaman dan level aktivitas fisik, status kecukupan energi, dan status antropometri. 


\section{Data Tingkat Aktivitas Fisik dan Pemahaman tentang Aktivitas Fisik}

Pengukuran level aktivitas fisik dilakukan dengan kuesioner IPAQ. Didapatkan hasil bahwa dari 30 orang mahasiswa mempunyai skor IPAQ rata-rata sebesar 7248,13 \pm 2420,58 METS dengan skor terendah sebesar 3800,00 METS dan skor tertinggi sebesar 11800,00 METS seperti tampak pada Gambar 1.

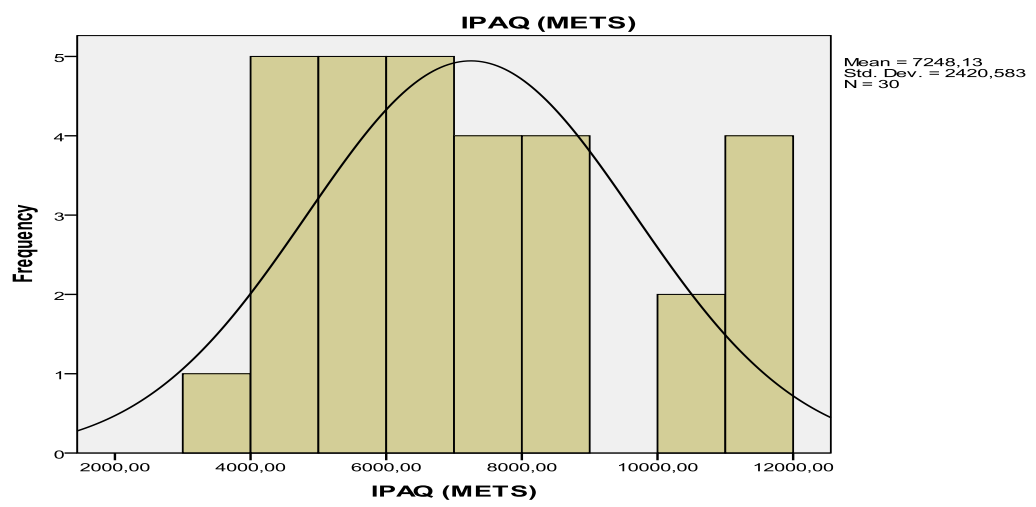

Gambar 1. Level Aktivitas Fisik (IPAQ)

Setelah diberikan materi tentang level aktivitas fisik, dilakukan pengukuran terhadap tingkat pemahaman terhadap materi yang diberikan. Diperoleh hasil bahwa pemahaman mahasiswa tentang level aktivitas fisik mencapai skor rata-rata sebesar $70,83 \pm 10,09 \%$ dengan skor terendah sebesar $50 \%$ dan skor tertinggi sebesar $85 \%$ (Gambar 2).

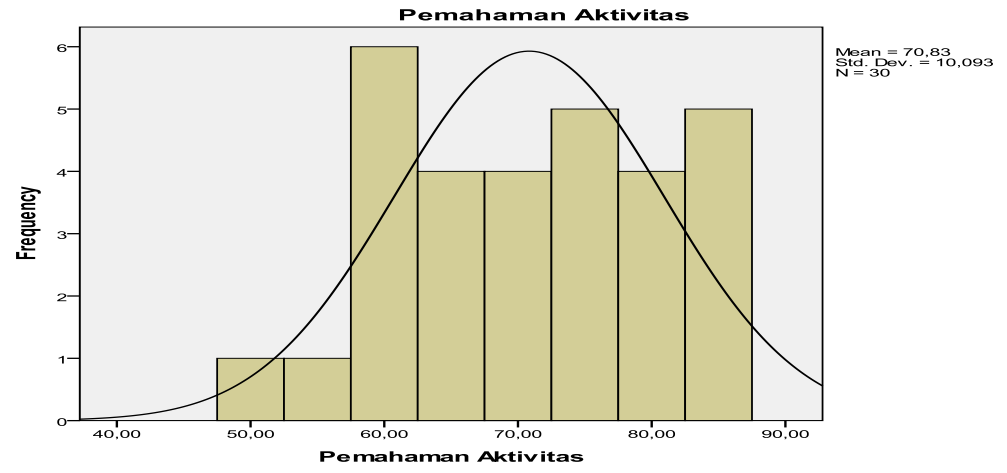

Gambar 2. Tingkat Pemahaman tentang Aktivitas Fisik

Tingkat Pemahaman dan Survei Level Aktivitas Fisik, Status Kecukupan Energi dan Status Antopometri Mahasiswa Program Studi Pendidikan Kepelatihan Olahraga FIK UNY (Prijo Sudibjo, Novita Intan Arovah, Rachmah Lakmi A) 
Scatter plot antara aktivitas fisik dan tingkat pemahaman mengindikasikan adanya hubungan linier. Scater plot beserta fungsi regresinya terlihat pada Gambar 3.

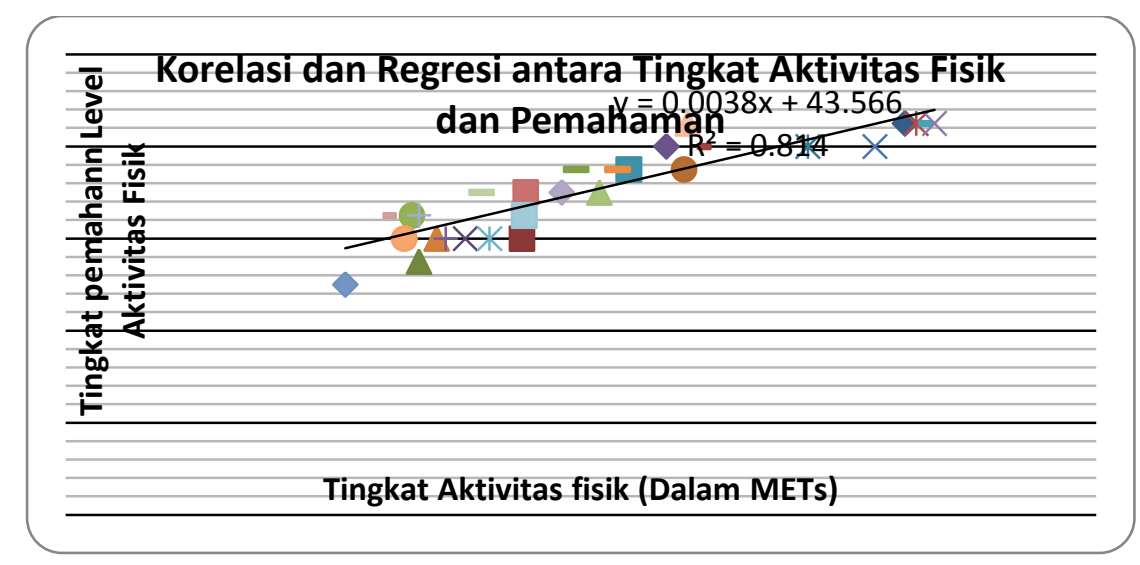

\section{Gambar 3. Analisis Korelasi antara Tingkat Aktivitas Fisik dan Pemahaman tentang Aktivitas Fisik}

Gambar 3 menunjukkan bahwa terdapat hubungan yang positif antara tingkat aktivitas fisik dan pemahaman tingkat aktivitas fisik, semakin tinggi tingkat pemahaman aktivitas fisiknya, semakin tinggi pula tingkat aktivitas fisiknya. Hal ini dapat dibuktikan dengan analisis korelasi Pearson yang menunjukkan angka sebesar positif 0,902 dengan taraf signifikansi kurang dari $0.05(0,00)$, yang berarti terdapat korelasi positif yang sangat kuat antara tingkat aktivitas fisik dan pemahaman tingkat aktivitas fisik (Sudijono, 2008).

\section{Data Kecukupan Energi dan Pemahaman tentang Kecukupan Energi}

Hasil penelitian menunjukkan bahwa rata-rata kecukupan energi atau gizi pada 30 mahasiswa adalah sebesar 96,62 $\pm 19,81 \%$ dengan nilai terendah sebesar 68,95\% dan tertinggi sebesar 135,22\% (Gambar 4). 


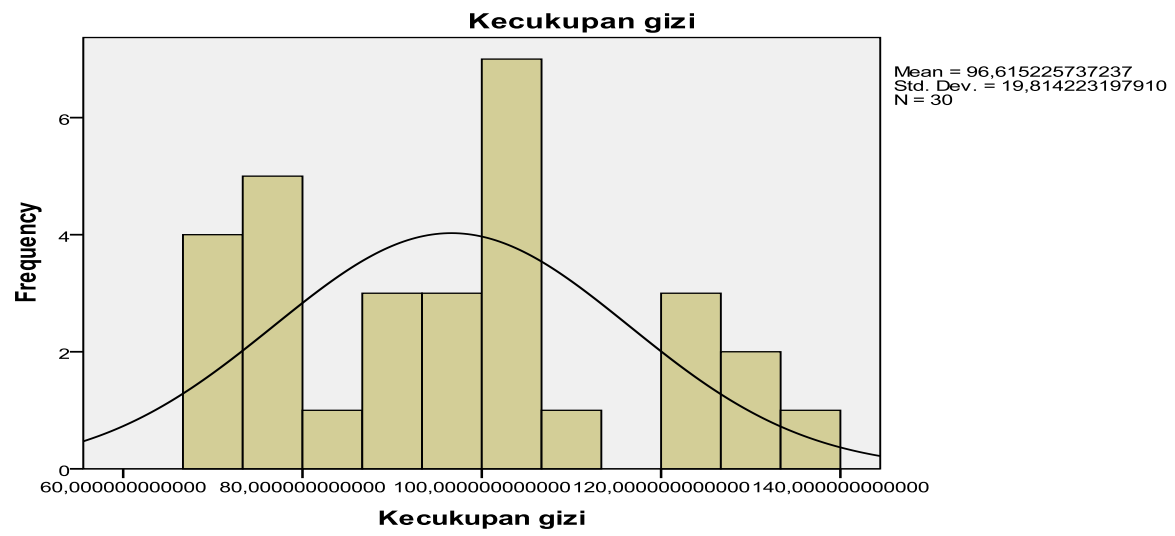

Gambar 4. Tingkat Kecukupan Energi

Skor tingkat pemahaman mahasiswa terhadap status kecukupan energi rata-rata sebesar 76 $\pm 16,99 \%$ dengan skor terendah sebesar 30\% dan skor tertinggi sebesar $100 \%$ (Gambar 5).



\section{Gambar 5. Tingkat Pemahaman terhadap Kecukupan Energi}

Scatter plot antara tingkat kecukupan energi dan tingkat pemahaman terhadap kecukupan energi mengindikasikan adanya hubungan linier. Scater plot beserta fungsi regresinya terlihat pada Gambar 6. 


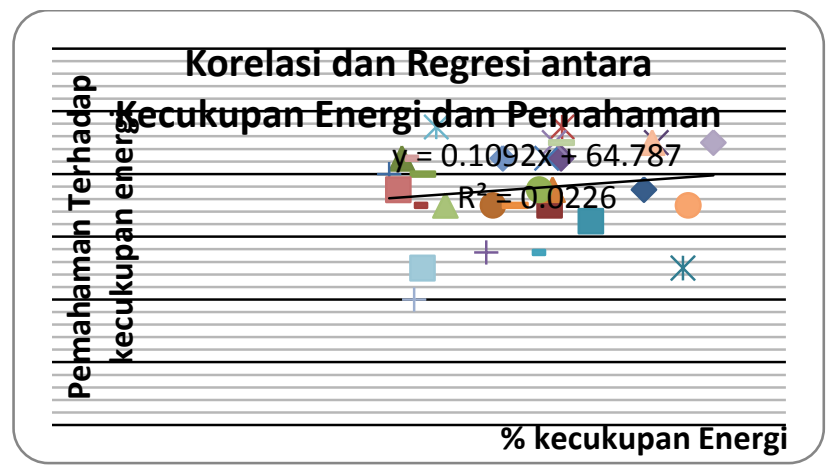

\section{Gambar 6. Analisis Korelasi antara Kecukupan Energi dan Pemahaman tentang Kecukupan Energi}

Sebaran yang tampak pada Gambar 6 menunjukkan adanya hubungan yang positif antara kecukupan energi dan pemahaman mahasiswa tentang kecukupan energi. Meskipun demikian, analisis statistik menunjukkan tidak adanya hubungan antara kecukupan energi dan pemahaman mahasiswa tentang kecukupan energi dengan taraf signifikansi sebesar 0,16 ( $\mathrm{p}>0,05)$.

\section{Data Status Gizi dan Pemahaman tentang Status Gizi}

Gambar 7 menunjukkan bahwa indeks massa tubuh (IMT) pada ketiga puluh mahasiswa mempunyai rata-rata sebesar 20,86 $\pm 1,75$ dengan nilai terendah sebesar 17,3 dan tertinggi sebesar 25,3.

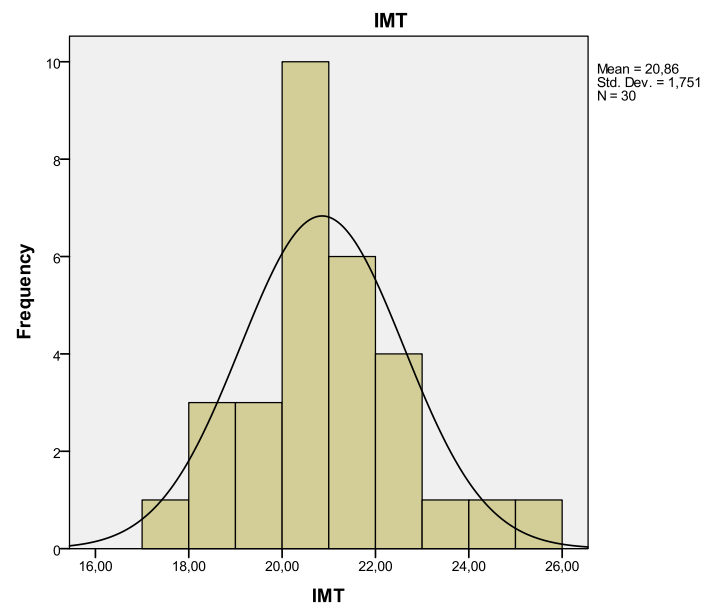

Gambar 7. Status Gizi dengan Indeks Massa Tubuh (IMT) 
Sebaran kriteria IMT dapat dilihat pada Tabel 3. Pada tabel 3 tampak bahwa sebagian besar mahasiswa (90 \%) mempunyai status gizi yang normal, dan hanya terdapat 6,67 \% yang mempunyai status gizi kurang BB ringan dan 3,33\% mempunyai status gizi kelebihan $\mathrm{BB}$ ringan.

Tabel 3. Klasifikasi Indeks Massa Tubuh (IMT) Mahasiswa

\begin{tabular}{|l|c|c|}
\hline \multicolumn{1}{|c|}{ Klasifikasi } & Frekuensi (N) & Persentase (\%) \\
\hline Kurang BB Berat & 0 & 0 \\
\hline Kurang BB Ringan & 2 & 90 \\
\hline Normal & 27 & 3,33 \\
\hline Kelebihan BB Ringan & 1 & 0 \\
\hline Kelebihan BB Berat & 0 & \\
\hline
\end{tabular}

Gambar 8 menunjukkan bahwa tingkat pemahaman status gizi serta cara penentuan status gizi dengan metode antropometri dan penentuan somatotipe menunjukkan skor rata-rata sebesar $75,33 \pm 14,38 \%$ dengan skor terendah sebesar $40 \%$ dan skor tertinggi sebesar $95 \%$.

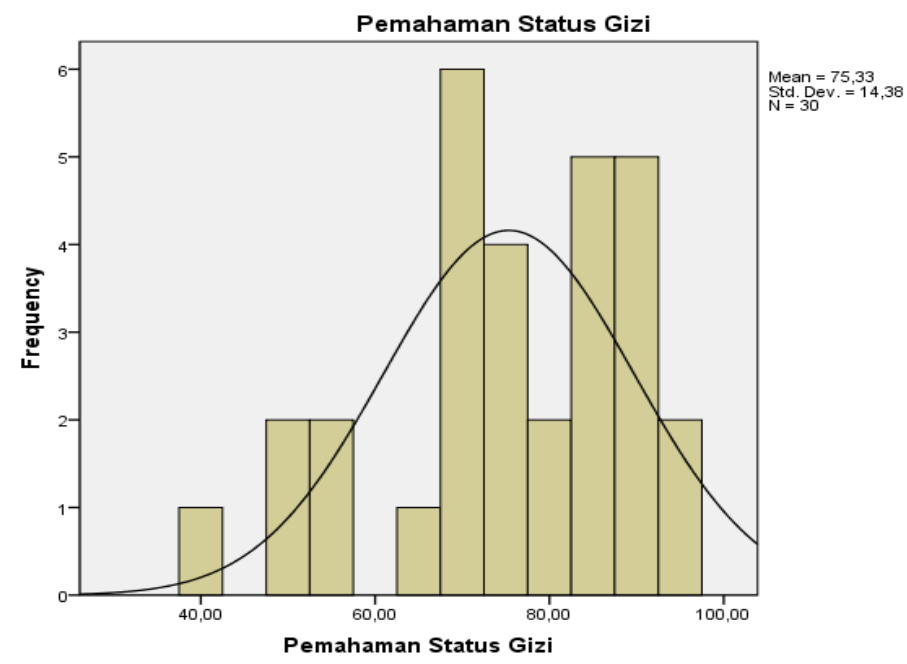

Gambar 8. Pemahaman tentang Status Gizi

Tingkat Pemahaman dan Survei Level Aktivitas Fisik, Status Kecukupan Energi dan Status Antopometri Mahasiswa Program Studi Pendidikan Kepelatihan Olahraga FIK UNY (Prijo Sudibjo, Novita Intan Arovah, Rachmah Lakmi A) 
Analisis korelasi Pearson seperti tampak pada Gambar 9 menunjukkan bahwa tidak terdapat korelasi antara status gizi dan pemahaman tentang status gizi, dengan taraf signifikansi 0,76 (p>0,05) dan nilai korelasi sebesar 0,05.



\section{Gambar 9. Analisis Korelasi antara Status Gizi dan Pemahaman tentang Status Gizi}

Pengukuran antropometri selain dapat menentukan status gizi dengan penghitungan IMT juga dapat dipergunakan untuk menentukan somatotipe seseorang. Tabel 4 menunjukkan tipe-tipe somatotipe mahasiswa yang ditentukan berdasarkan Health Charter Manual. Klasifikasi somatotipe terbanyak dari 30 mahasiswa tersebut adalah balance mesomorph sebesar $30 \%$ disusul dengan ectomorphic mesomorph sebesar $20 \%$ dan mesomorph ectomorph sebesar $16,67 \%$.

Tabel 4. Kriteria Somatotipe Mahasiswa berdasarkan Health Charter Manual

\begin{tabular}{|l|c|c|}
\hline \multicolumn{1}{|c|}{ Somatotipe } & Frekuensi (N) & Persentase (\%) \\
\hline Ectomorphic Endomorph & 1 & 3.33 \\
\hline Ectomorphic Mesomorph & 6 & 20 \\
\hline Mesomorphic Ectomorph & 2 & 6,67 \\
\hline Mesomorph Ectomorph & 5 & 16,67 \\
\hline Mesomorph Endomorph & 3 & 10 \\
\hline Endomorphic Ectomorph & 1 & 3,33 \\
\hline Endomorphic Mesomorph & 2 & 6,67 \\
\hline Balanced Mesomorph & 9 & 30 \\
\hline Central & 1 & 3,33 \\
\hline \multicolumn{1}{|c|}{ JUMLAH } & $\mathbf{3 0}$ & $\mathbf{1 0 0}$ \\
\hline
\end{tabular}




\section{PEMBAHASAN}

Mahasiswa Program Studi Pendidikan Kepelatihan Olahraga (PKO) dituntut untuk memahami dan mampu mengukur tingkat kebutuhan energi, level aktivitas fisik, dan status gizi, serta klasifikasi somatotipe sehingga diharapkan dapat mengelola atletnya agar memiliki status antropometri yang optimal. Diketahui bahwa kesuksesan atlet dalam berprestasi harus ditunjang oleh profil anatomis (status antropometri) yang baik sehingga diperlukan strategi latihan fisik yang tepat serta status kecukupan energi yang baik (Oja $e t$ al, 2004: 18).

Aktivitas fisik disebut juga aktivitas eksternal yaitu sesuatu yang menggunakan tenaga atau energi untuk melakukan berbagai kegiatan fisik, seperti berjalan, berlari, dan berolahraga (Haskell et al, 2007: 1423). Pengukuran level aktivitas fisik pada atlet penting dilakukan sebagai bentuk evaluasi program latihan yang telah dilaksanakan dan selanjutnya evaluasi dapat digunakan sebagai perencanaan program latihan lanjutan (Wilmore et al. 2004). Selain itu, hasil pengukuran tingkat aktivitas fisik diperlukan untuk mengukur kebutuhan energi atlet.

Hasil penilaian aktivitas fisik dalam penelitian ini menunjukkan nilai aktivitas fisik yang cukup tinggi pada semua subjek dengan pemahaman yang cukup baik pula. Selanjutnya pada penelitian ini diperoleh hasil bahwa terdapat korelasi positif yang sangat kuat antara tingkat pemahaman level aktivitas fisik dan level aktivitas fisik (korelasi 0.902). Hasil ini menunjukkan bahwa semakin tinggi tingkat pemahaman seorang mahasiswa tentang level aktivitas fisik, semakin besar pula level aktivitas fisiknya. Hal ini sesuai dengan hasil penelitian Roberts and Marvin (2011) yang menyimpulkan bahwa pengetahuan dan perilaku tentang makanan sehat dan aktivitas fisik terbukti secara signifikan sebagai penentu terhadap pemilihan makanan sehat dan level aktivitas fisik seseorang. Walaupun demikian level aktivitas fisik yang tinggi tersebut mungkin tidak hanya disebabkan oleh tingkat pemahaman yang tinggi. Hal ini bisa pula terjadi karena subjek merupakan mahasiswa semester satu yang masih harus banyak mengikuti kuliah dasar gerak olahraga yang merupakan aktivitas fisik sedang sampai berat. Dengan kata lain

Tingkat Pemahaman dan Survei Level Aktivitas Fisik, Status Kecukupan Energi dan Status Antopometri Mahasiswa Program Studi Pendidikan Kepelatihan Olahraga FIK UNY (Prijo Sudibjo, Novita Intan Arovah, Rachmah Lakmi A) 
status hubungan sebab akibat dalam analisis korelasional ini masih harus ditinjau dengan penelitian lanjutan.

Berbeda dengan hasil penelitian Roberts and Marvin di atas, pada penelitian ini ternyata tidak terbukti adanya korelasi antara kecukupan energi dan pengetahuan dan pemahaman tentang kecukupan energi, dengan taraf signifikansi sebesar 0,16 ( $\mathrm{p}>0,05)$. Penelitian ini juga menunjukkan tidak adanya korelasi antara status gizi dan pemahaman tentang status gizi dengan taraf signifikansi sebesar 0,76 ( $\mathrm{p}>0,05)$ dan nilai korelasi sebesar 0,05. Meskipun demikian apabila dilihat tingkat pemahaman mahasiswa terhadap status kecukupan energi dan tingkat pemahaman status gizi serta cara penentuan status gizi dengan metode antropometri dan penentuan somatotipe menunjukkan nilai rata-rata yang cukup bagus, yaitu berturut-turut sebesar $76 \pm 16,99 \%$ dan 75,33 $\pm 14,38 \%$.

Hal ini mungkin disebabkan oleh faktor ekonomi yang dapat mempengaruhi daya beli mahasiswa untuk memperoleh makanan yang sehat, meskipun mereka sebenarnya memiliki pengetahuan yang baik tentang kecukupan energi dan status gizi. Roberts dan Marvin (2011) mengatakan bahwa hambatan utama untuk memperoleh makanan yang sehat adalah karena mahalnya harga makanan sehat, di samping sulitnya mengubah kebiasaan makan yang kurang sehat dan tidak tersedianya waktu yang cukup untuk mendapatkan makanan yang sehat. Hal ini juga dapat diakibatkan oleh kurang telitinya mahasiswa dalam melakukan food-recalling. Mahasiswa cenderung melaporkan asupan makanan yang kaya kalori seperti gula dan minyak. Mereka juga banyak yang kurang tepat dalam mengonversikan ukuran rumah tangga dengan satuan metrik.

Penting bagi mahasiswa untuk memahami tentang level aktivitas fisik dan kecukupan energi, karena menurut (Reeves Jr et al, 1999: 79) level aktivitas fisik dan status kecukupan energi yang optimal dapat mendukung status antropometri yang ideal pada atlet. Untuk dapat menentukan status antropometri yang ideal pada atlet, diperlukan upaya untuk menentukan somatotipe seorang atlet agar dapat ditentukan status antropometri yang paling optimal dalam cabang olahraga tertentu. Somatotipe seseorang lebih bersifat phenotype daripada genotype, yang mengimplikasikan bahwa somatotipe bisa dimodifikasi dengan latihan dan pengaturan asupan gizi. Beberapa penelitian yang membandingkan sekelompok atlet dan nonatlet menunjukkan bahwa pada atlet memiliki lemak yang sedikit dengan 
massa tubuh tanpa lemak yang jauh lebih besar dibandingkan dengan yang non athlet. Dengan demikian penampilan seorang atlet dapat dipengaruhi oleh faktor genetik seperti tinggi badan dan juga latigan fisik dan pengaturan asupan makanan (Abernethy et al,1996).

Pada penelitian ini, tampak bahwa mahasiswa sudah mampu menentukan level aktivitas fisik, status kecukupan energi, dan status antropometri secara teoretis, namun masih diperlukan upaya untuk meningkatkan keterampilan mahasiswa dalam mengaplikasikan ilmu yang didapat ke dalam praktik. Pada penentuan status antropometri mahasiswa lebih ditekankan pada kemampuan menentukan status gizi seseorang secara antropometris dan kemampuan menentukan somatotipe, sehingga mahasiswa nantinya mampu menempatkan seorang atlet sesuai dengan kecabangannya berdasarkan somatotipenya. Metode penentuan somatotipe yang sering dilakukan adalah somatotype berdasarkan Heath Charter Manual. . 


\section{KESIMPULAN DAN SARAN}

Dari hasil penelitian dapat disimpulkan bahwa mahasiswa Program Studi Pendidikan Kepelatihan Olahraga FIK UNY memiliki tingkat aktivitas fisik, status kecukupan energi, dan status gizi yang memadai, serta memiliki tingkat pemahaman terhadap aktivitas fisik, status kecukupan energi, dan status gizi yang cukup baik pula. Masih diperlukan upaya untuk meningkatkan keterampilan mahasiswa dalam mengaplikasikan ilmu yang didapat ke dalam praktik. Di samping itu juga didapatkan adanya hubungan korelasional yang bermakna antara tingkat pemahaman dan level aktivitas fisik. Meskipun demikian, tidak terdapat hubungan korelasional yang bermakna antara tingkat pemahaman dan status gizi dan tingkat status kecukupan energi. Dengan demikian diperlukan upaya untuk lebih meningkatkan pemahaman dan keterampilan mahasiswa Program Studi Pendidikan Kepelatihan Olahraga dalam pengukuran level aktivitas fisik, status kecukupan energi, dan status gizi secara antropometrik. 


\section{DAFTAR PUSTAKA}

Abernethy, Bruce et al. (1996). The Biophysical Foundations of Human Movement. Human Kinettics, Quinsland, Australia.

Booth, M. L., B. E. Ainsworth, M. Pratt, U. L. F. Ekelund, A. Yngve, J. F. Sallis and P. Oja. (2003). "International Physical Activity Questionnaire: 12-country reliability and validity." Medicine \& Science in Sports \& Exercise 195(9131/03): 1381.

Haskell, W. L., I. Lee, R. R. Pate, K. E. Powell, S. N. Blair, B. A. Franklin, C. A. Macera, G. W. Heath, P. D. Thompson and A. Bauman (2007). "Physical activity and public health: updated recommendation for adults from the American College of Sports Medicine and the American Heart Association." Medicine and science in sports and exercise 39(8): 1423.

Jahari, A. B. (1998). "Antropometri sebagai Indikator Status Gizi." Gizi Indonesia 13: 54.

Jelliffe, D. B. (2006). "The Assessment of the Nutritional Status of the Community." 135.

Lee-Han, H., V. McGuire and N. F. Boyd (2009). "A Review of the Methods Used by Studies of Dietary Measurement." Journal of Clinical Epidemiology 42(3): 269.

Livingstone, M. B. E. and P. J. Robson (2000). "Measurement of Dietary Intake " Proceedings of the Nutrition Society 59(02): 293.

Martins, I. S. and S. P. Marinho (2003). "The Potential of Central Obesity Antropometric Indicators as Diagnostic Tools." Revista de SaÃ ${ }^{\circ}$ de PÃ ${ }^{\circ} b l i c a$ 37(6): 760.

Oja, L. and Toivo (2004). "Relationships Between Physical Activity, Motor Ability, and Antropometric Variables in Athlete." 18.

Reeves Jr, S., B. Poh, M. Brown, N. Tizzard and M. Ismail (1999). "Antropometric Measurements and Body Composition of English and Malaysian Footballers." Malaysian journal of nutrition 5(1): 79.

Wilmore, J. H. and Costill, D. L. (2004). Physiology of Sport and Exercise, Human Kinetics Publishers, United States of America. 